\title{
Unfinished battle with childhood tuberculosis: is it curable with less drugs and shorter duration?
}

\author{
Güzin CINEL ${ }^{1}$, Nural KIPER ${ }^{1}$, Sevgi PEKCAN ${ }^{2}$, Mustafa KOYUN ${ }^{3}$, Mehmet KÖSE ${ }^{4}$, Nazan ÇOBANOĞLU ${ }^{5}$, \\ Ayşe TANA ASLAN ${ }^{6}$, Ebru YALÇIN ${ }^{1}$, Deniz DOĞRU ${ }^{1}$, Uğur ÖZÇELIK ${ }^{1}$, Ayhan GÖÇMEN ${ }^{1}$ \\ ${ }^{1}$ Hacettepe Üniversitesi Tıp Fakültesi, Çocuk Sağlığı ve Hastalıkları Anabilim Dalı, Çocuk Göğüs Hastalıkları Bilim Dalı, \\ Ankara, \\ ${ }^{2}$ Necmettin Erbakan Üniversitesi Meram Tıp Fakültesi, Çocuk Sağlığı ve Hastalıkları Anabilim Dalı, Çocuk Göğüs \\ Hastalıkları Bilim Dalı, Konya, \\ ${ }^{3}$ Akdeniz Üniversitesi Tıp Fakültesi, Çocuk Sağlığı ve Hastalıkları Anabilim Dalı, Çocuk Nefroloji Ünitesi, Antalya, \\ ${ }^{4}$ Erciyes Üniversitesi Tıp Fakültesi, Çocuk Sağlığı ve Hastalıkları Anabilim Dalı, Çocuk Göğüs Hastalıkları Ünitesi, Kayseri, \\ ${ }^{5}$ Yakın Doğu Üniversitesi Tıp Fakültesi, Çocuk Sağlığı ve Hastalıkları Anabilim Dalı, Çocuk Göğüs Hastalıkları Bilim Dalı, \\ Lefkoşa, \\ ${ }^{6}$ Gazi Üniversitesi Tıp Fakültesi, Çocuk Sağlığı ve Hastalıkları Anabilim Dalı, Çocuk Göğüs Hastalıkları Bilim Dalı, Ankara
}

\section{ÖZET}

Çocukluk çağı tüberkülozu ile bitmeyen savaş: Daha az ilaç ve daha kısa sürede tedavi edilebilir mi?

Giriş: Etkili tedavi rejimleriyle mortalitesi tüm dünyada azalmış olsa da tüberküloz halen global bir sağlık problemidir. Tedaviye uyumsuzluk, ilaç direnci, tedavi başarısızlığı ve relaps tüberküloz tedavisi sırasında sık karşılaşılan problemlerdir. Intermittan tedavi rejimlerinin, özellikle kaynakları sınırlı bölgelerde, tedavi maliyetini ve tedavinin yan etkilerini azalttığl, hastanın tedaviye uyumunu artırdığı bilinmektedir; ayrıca çocuk hastalarda da her gün verilen tedavi kadar etkili olduğu gösterilmiştir. Bu çalışmada, hastanemizde pulmoner ve ekstrapulmoner tüberküloz tanısı almış çocuk hastalara iki ilaçla verilen 6 ve 9 aylık intermittan tüberküloz tedavi rejimlerinin sonuçları karşılaştırılmıştır.

Materyal ve Metod: Hastanemizde 1986 ile 2001 yılları arasında akciğer, lenf nodu, iskelet sistemi, pleural, abdominal, miliyer, perikardiyal, deri ve böbrek tüberkülozu nedeniyle intermittan antitüberküloz tedavi alan 115 hasta retrospektif olarak değerlendirilmiştir. Elli bir hastaya 15 gün süreyle izoniazid ve rifampisin tedavisi sonrası 9 ay süreyle aynı ilaçlarla ve aynı dozlarda haftada iki gün intermittan tedavi verilmiştir. Altmış dört hastaya ise aynı tedavi rejimi 6 ay süreyle uygulanmiştır.

Bulgular: Tedavinin ilk ayında 1. gruptaki (9 aylı intermittan tedavi) pulmoner tüberkülozlu hastaların \%75'inde, 2. gruptaki (6 aylık intermittan tedavi) pulmoner tüberkülozlu hastaların \%79'unda klinik düzelme gözlendi. Pulmoner tüberkülozlu hastalarda ilk 6 ayda, grup 1'de \%81'inde, grup 2'de \%86'sında radyolojik düzelme görüldü. Klinik ve radyolojik düzelme zamanları karşılaştırıldığında iki grup arasında anlamlı bir farklllık saptanmadı ( $p>0.05)$. Benzer sonuçlar ekstrapulmoner tüberkülozlu hastalarda da gözlendi ( $p>0.05$ ). Hastalar 7 ay ile 15 yll arasında takip edildi. Hiçbir olguda erken relaps gözlenmedi. Dokuz aylık intermittan tedavi alan (grup 1) 4 hastada, tedavi kesildikten iki yıl sonra geç relaps görüldü.

\footnotetext{
Yazışma Adresi (Address for Correspondence):

Dr. Güzin CiNEL, Hacettepe Üniversitesi Tıp Fakültesi, Çocuk Sağlığı ve Hastalıkları Anabilim Dalı, Çocuk Göğüs Hastalıkları Bilim Dalı, ANKARA - TURKEY

e-mail: guzincinel@yahoo.com
} 
Sonuç: Çocukluk çağı pulmoner ve menenjit dışı ekstrapulmoner tüberkülozda, iki ilaçla 6 aylık intermittan tedavi, 9 aylık intermittan tedavi kadar etkilidir.

Anahtar Kelimeler: Çocukluk çağı tüberkülozu, intermittant antitüberküloz tedavi.

\title{
SUMMARY
}

\section{Unfinished battle with childhood tuberculosis: is it curable with less drugs and shorter duration?}

\author{
Güzin CINEL ${ }^{1}$, Nural KIPER ${ }^{1}$, Sevgi PEKCAN ${ }^{2}$, Mustafa KOYUN $^{3}$, Mehmet KÖSE $^{4}$, Nazan ÇOBANOĞLU ${ }^{5}$, \\ Ayşe TANA ASLAN ${ }^{6}$, Ebru YALÇIN ${ }^{1}$, Deniz DOĞRU ${ }^{1}$, Uğur ÖZÇELIK ${ }^{1}$, Ayhan GÖÇMEN ${ }^{1}$
}

${ }^{1}$ Division of Pediatric Chest Diseases, Department of Children's Health and Diseases, Faculty of Medicine, Hacettepe University, Ankara, Turkey,

2 Division of Pediatric Chest Diseases, Department of Children's Health and Diseases, Faculty of Meram Medicine, Necmettin Erbakan University, Konya, Turkey,

3 Unit of Pediatric Nephrology, Department of Children's Health and Diseases, Faculty of Medicine, Akdeniz University, Antalya, Turkey,

${ }^{4}$ Unit of Pediatric Chest Diseases, Department of Children's Health and Diseases, Faculty of Medicine, Erciyes University, Kayseri, Turkey,

${ }^{5}$ Division of Pediatric Chest Diseases, Department of Children's Health and Diseases, Faculty of Medicine Near East University, Nikosia, Cyprus,

${ }^{6}$ Division of Pediatric Chest Diseases, Department of Children's Health and Diseases, Faculty of Medicine, Gazi University, Ankara, Turkey.

Introduction: Tuberculosis is still a global health problem all over the world despite its mortality has been decreased with effective treatment regimens. Poor treatment adherence, acquired drug resistance, treatment failure and relapse are the major problems during the course of the tuberculosis treatment. Intermittent regimens have the advantages of reducing the side effects and the cost of the therapy and increasing the adherence, especially in resource-limited areas; and have been documented to be as effective as daily regimen in the paediatric population. In this study, we compared the results of 6-month and 9-month intermittent-therapy regimens with two drugs, given to the children with pulmonary and extrapulmonary tuberculosis at our hospital.

Materials and Methods: One hundred and fifteen patients with pulmonary and extrapulmonary tuberculosis other than meningitis, who had been given intermittent anti-tuberculosis therapy between 1986 and 2001, were evaluated retrospectively. Fifty one patients were given isoniazid and rifampin daily for 15 days, followed by the same drugs and doses twice weekly for a total of 9-months. Also, 64 patients were treated with the same regimen for a total of 6-months.

Results: Clinical recovery was observed in 75\% and 79\% of pulmonary tuberculosis patients at the first month of therapy in group 1 (9-month group) and group 2 (6-month group), respectively. Radiological recovery was noted between 0-6 months in $81 \%$ of the patients in group 1 and $86 \%$ of the patients in group 2. According to the clinical and radiological recovery times, no significant difference was detected between the two groups $(p>0.05)$. Similar results had been observed in extrapulmonary tuberculosis ( $p>0.05$ ). Follow-up periods ranged from 7 months to 15 years. There was no case of early relapse. Late relapse was noted in 4 patients, who had been received 9-month therapy (group 1).

Conclusion: Six-month intermittent therapy with two drugs is as efficacious as 9-month intermittent-therapy in childhood pulmonary and extrapulmonary tuberculosis, other than meningitis.

Key Words: Childhood tuberculosis, intermittent anti-tuberculosis treatment

Tuberk Toraks 2013; 61(4): 320-326 • doi: 10.5578/tt.3890

\section{INTRODUCTION}

Tuberculosis (TB), which was responsible for millions of deaths in the epidemics between $17^{\text {th }}$ and $19^{\text {th }}$ century, is the leading cause of death associated with in- fectious diseases globally (1). Although its mortality has been decreased with effective treatment regimens, TB is still a global health problem all over the world. An estimated one-third of the world's population is infected with TB (2). TB accounted for 1.3 million deaths in 
2007 , and the prevalence of active disease is estimated at 13.7 million (206 per 100.000 persons) (3). In many countries with high TB incidence, childhood TB (i.e. TB among the population aged less than 15 years) constitutes a significant proportion (approximately 11-14\%) of the TB case-load and under- 5 mortality $(4,5)$. Of the estimated 9.3 million annual incident TB cases in the world in the year 2007, at least 1 million are estimated to be less than 15 years of age (3).

Despite the availability of effective chemotherapy regimens against this ancient disease, world's battle with this old human enemy is still far from over. Poor treatment adherence, acquired drug resistance, treatment failure and relapse have been encountered since the early days of chemotherapy (6). Although during the last few years dramatic changes have occurred in the therapeutic approaches to childhood TB as a result of large number of treatment trials for children, there is no consensus on the treatment of children with TB. The American Academy of Pediatrics, American Thoracic Society, British Thoracic Society and WHO recommend different regimens ${ }^{\circledR}$.

Intermittent regimens have been documented to be as effective as daily regimen in the paediatric population (7-10). Intermittent drug delivery either throughout the entire 6-month course or only during the continuation phase in the last 4 months has been widely adopted to facilitate treatment supervision on an outpatient basis. Intermittent therapy has the advantages of reducing the side effects, reducing the cost of the therapy and increasing the adherence of the patient to the therapy, especially in resource-limited areas or for underprivileged segments of populations.

In this study, we compared the results of 6-month and 9 -month intermittent therapy regimens with two drugs, given to the children with pulmonary and extrapulmonary TB at our hospital.

\section{MATERIALS and METHODS}

One hundred and fifteen patients with pulmonary, lymph node, musculoskeletal, pleural, abdominal, miliary, pericardial, skin and renal tuberculosis, who had been given intermittent anti-tuberculosis therapy at our hospital between 1986 and 2001, were evaluated retrospectively. The exact diagnosis was based on clinical and radiological evidence, on the history of contact with an adult with TB, result of the tuberculin skin test (TST), positive cultures and histopathological evidence of TB. Lymph node enlargement, consolidation, atelectasis, miliary mottling, cavitation, calcification or pleural effusion on chest roentgenogram were in favor of tuberculosis. Tuberculin skin test was considered positive in children without BCG and with BCG over $10 \mathrm{~mm}$ and over $15 \mathrm{~mm}$, respectively. Sputum, gastric lavage, pleural and pericardial fluid, and urine specimens were observed for acid fast bacilli and were inoculated on to Lowenstein-Jensen medium. Histopathologic examinations were done on specimens of lymph nodes $(n=12)$, bone $(n=7)$, liver $(n=$ $1)$, lung $(n=1)$ and skin $(n=1)$ tissues.

Fifty one patients were given isoniazid (10-15 mg/kg) and rifampin (10-15 mg/kg) daily for 15 days, followed by the same drugs and doses twice weekly for a total of 9 months. Also, 64 patients were treated with the same regimen for a total of 6 months.

Improvement in appetite and weight gain, normalization of body temperature and cessation of sweating in all patients, cessation of coughing in pulmonary TB patients, reduction in lymph node size in lymph node TB patients, and improvement of local pain and swelling in musculoskeletal TB, were accepted as criteria for clinical recovery during the course of treatment. Resolution of infiltrates, hilar adenopathy, miliary mottling and pleural effusion on chest roentgenogram, and improvement in distension of joint capsule and soft tissue swelling, periosteal reaction, cortical irregularity and demineralization on bone and joint roentgenogram, were accepted as criteria of radiological recovery.

Patients were followed up during and after treatment, initially after 1, 3 and 6 months, and later at annual intervals.

\section{Statistics}

Statistical analysis was performed using chi-squared test. The results were considered significant when $p$ was lower than 0.05 .

\section{RESULTS}

Of the total of 115 patients, 51 received 9-month therapy (group 1) and 64 received 6-month therapy (group 2). Male/female (M/F) ratio was 1.2 in group 1 and 0.7 in group 2. Distribution of the patients according to their age groups are shown in Table 1.

$47 \%$ and $73 \%$ of the patients had pulmonary TB in group 1 and group 2, respectively. The most common extrapulmonary localization was peripheral lymph nodes in both groups, followed by musculoskeletal, pleural, abdominal, miliary, pericardial, renal and skin tuberculosis (Table 2).

Close contact with an adult TB was detected in 35 patients (30.4\%). Twenty two (19.1\%) patients had no BCG vaccination. Tuberculin skin test was positive in 83 children (72\%). Examination of biopsy specimens 
Table 1. Distribution of the patients according to age groups

\begin{tabular}{|c|c|c|c|c|c|c|}
\hline \multirow[b]{2}{*}{ Age group (year) } & \multicolumn{2}{|c|}{ Group 1} & \multicolumn{2}{|c|}{ Group 2} & \multicolumn{2}{|c|}{ Total } \\
\hline & $\mathbf{n}$ & $\%$ & $\mathbf{n}$ & $\%$ & $\mathbf{n}$ & $\%$ \\
\hline $0-5$ & 23 & 45.1 & 22 & 34.4 & 45 & 39.1 \\
\hline $6-12$ & 19 & 37.3 & 32 & 50.0 & 51 & 44.3 \\
\hline $12-16$ & 9 & 17.7 & 10 & 15.6 & 19 & 16.5 \\
\hline Total & 51 & 100.0 & 64 & 100.0 & 115 & 100.0 \\
\hline
\end{tabular}

\section{Table 2. Site of tuberculosis}

\begin{tabular}{|c|c|c|c|c|c|c|}
\hline \multirow[b]{2}{*}{ Site } & \multicolumn{2}{|c|}{ Group 1} & \multicolumn{2}{|c|}{ Group 2} & \multicolumn{2}{|c|}{ Total } \\
\hline & $\mathbf{n}$ & $\%$ & $n$ & $\%$ & $\mathbf{n}$ & $\%$ \\
\hline Pulmonary & 24 & 47.1 & 47 & 73.4 & 71 & 61.7 \\
\hline Lymph nodes & 11 & 21.6 & 6 & 9.4 & 17 & 14.8 \\
\hline Musculoskeletal & 8 & 15.7 & 2 & 3.1 & 10 & 8.7 \\
\hline Pleural & 2 & 3.9 & 4 & 6.3 & 6 & 5.2 \\
\hline Abdominal & 3 & 5.9 & 2 & 3.1 & 5 & 4.3 \\
\hline Miliary & 2 & 3.9 & 1 & 1.6 & 3 & 2.6 \\
\hline Pericardial & 1 & 2.0 & & & 1 & 0.9 \\
\hline Skin & & & 1 & 1.6 & 1 & 0.9 \\
\hline Renal & & & 1 & 1.6 & 1 & 09 \\
\hline Total & 51 & 100.0 & 64 & 100.0 & 115 & 100.0 \\
\hline
\end{tabular}

from lymph nodes $(n=12)$, bone $(n=7)$, liver $(n=1)$, lung $(n=1)$ and skin $(n=1)$ tissues showed granulomatous inflammation, which was compatible with tuberculosis. The cultures were positive in 9 pulmonary, two miliary, one pleural and one musculoskeletal TB patients. The pulmonary TB cases were generally diagnosed by means of clinical and radiological evidences and positive TST. The criteria supporting the diagnosis of TB was shown in Table 3.

Clinical recovery was observed in 75 and 79 percent of pulmonary TB patients at the first month of therapy in group 1 and group 2, respectively (Table 4). Radiological recovery was noted between 0-6 months in 81 percent of the patients in group 1 and 86 percent of the patients in group 2 (Table 4). According to the clinical and radiological recovery times, no significant difference was detected between the two groups ( $p>0.05$ ). Similar results had been observed in extrapulmonary TB, although the recovery was longer in these patients ( $p$ > 0.05) (Table 5). Amazingly, we observed that radiological recovery in group 1 (9-month group) was longer than in group 2.
Follow-up periods ranged from 7 months to 15 years (Table 6). There was no case of early relapse. Late relapse was noted in 4 patients, who had been received 9-month therapy (group 1) two years after the termination of treatment. Two of these patients had immunodeficiency. Three had pulmonary and one had lymph node TB.

\section{DISCUSSION}

TB is still one of the deadliest diseases in the world killing nearly 2 million people every year. More than ninety percent of all tuberculosis cases occur in the developing countries, where limited resources are available for optimal treatment; also TB infection and disease among children are much more prevalent in these countries (2) where the annual risk is estimated to be 2-5 percent. The estimated lifetime risk of developing TB disease for a young child infected with Mycobacterium tuberculosis as indicated by positive tuberculin test is about 10 percent (3). Nearly $8-20$ percent of the deaths caused by TB occur in children (4). The age of the child at acquisition of TB infection has a great effect on the occurrence of tuberculosis disease. (Kabra 
Table 3. The criteria supporting the diagnosis of tuberculosis

\begin{tabular}{|c|c|c|c|c|c|c|}
\hline \multirow[b]{2}{*}{ Criteria } & \multicolumn{3}{|c|}{ Pulmonary tuberculosis } & \multicolumn{3}{|c|}{ Extrapulmonary tuberculosis } \\
\hline & $\begin{array}{c}\text { Group } 1 \\
n=24(\%)\end{array}$ & $\begin{array}{c}\text { Group } 2 \\
<\mathrm{n}=47 \quad(\%)\end{array}$ & $\begin{array}{c}\text { Total } \\
\mathrm{n}=71(\%)\end{array}$ & $\begin{array}{c}\text { Group } 1 \\
n=27(\%)\end{array}$ & $\begin{array}{c}\text { Group } 2 \\
n=17(\%)\end{array}$ & $\begin{array}{c}\text { Total } \\
n=44(\%)\end{array}$ \\
\hline Clinical & $24(100)$ & $47(100)$ & $71(100)$ & $27(100)$ & $17(100)$ & $44(100)$ \\
\hline Radiologic & $23(96)$ & $42(89)$ & $65(92)$ & $15(56)$ & $7(41)$ & $22(50)$ \\
\hline TST positive & $17(71)$ & $38(81)$ & $55(77)$ & $17(63)$ & $11(65)$ & $28(64)$ \\
\hline Contact & $7(29)$ & $17(36)$ & $24(34)$ & $9(33)$ & $2(12)$ & $11(25)$ \\
\hline Bacteriologic & $4(17)$ & $15(32)$ & $19(27)$ & $4(15)$ & $5(29)$ & $9(20)$ \\
\hline Pathologic & $1(4)$ & - & $1(1)$ & $15(56)$ & $6(35)$ & $21(48)$ \\
\hline
\end{tabular}

Table 4. Duration of clinical and radiological recovery of pulmonary tuberculosis patients

\begin{tabular}{|c|c|c|c|c|c|c|c|}
\hline \multirow[b]{2}{*}{$\begin{array}{l}\text { Duration } \\
\text { (months) }\end{array}$} & \multicolumn{3}{|c|}{ Clinical recovery } & \multicolumn{4}{|c|}{ Radiological recovery } \\
\hline & $\begin{array}{c}\text { Group } 1 \\
\text { n (\%) }\end{array}$ & $\begin{array}{c}\text { Group } 2 \\
\text { n (\%) }\end{array}$ & $\begin{array}{l}\text { Total } \\
\text { n (\%) }\end{array}$ & $\begin{array}{c}\text { Group } 1 \\
\text { n (\%) }\end{array}$ & $\begin{array}{c}\text { Group } 2 \\
\text { n (\%) }\end{array}$ & $\begin{array}{l}\text { Total } \\
\text { n (\%) }\end{array}$ & \\
\hline $0-1$ & $18(75.0)$ & $37(78.7)$ & $55(77.5)$ & $1(4.8)$ & $3(8.3)$ & $4(7.0)$ & \\
\hline $2-3$ & $4(16.7)$ & $7(14.9)$ & $11(15.5)$ & $8(38.1)$ & $10(27.8)$ & $18(31.6)$ & \\
\hline $4-6$ & $2(8.3)$ & $3(6.4)$ & $5(7.0)$ & $8(38.1)$ & $18(50.0)$ & $26(45.6)$ & \\
\hline $7-9$ & - & - & - & $4(19.0)$ & - & $4(7.0)$ & \\
\hline $10-12$ & - & - & - & - & $5(13.9)$ & $5(8.8)$ & \\
\hline Total & $24(100.0)$ & $47(100.0)$ & $71(100.0)$ & $21(100.0)$ & $36(100.0)$ & $57(100.0)$ & $p>0.05$ \\
\hline
\end{tabular}

Table 5. Duration of clinical and radiological recovery of extrapulmonary tuberculosis

\begin{tabular}{|c|c|c|c|c|c|c|}
\hline \multirow[b]{2}{*}{$\begin{array}{l}\text { Duration } \\
\text { (months) }\end{array}$} & \multicolumn{3}{|c|}{ Clinical recovery } & \multicolumn{3}{|c|}{ Radiological recovery } \\
\hline & $\begin{array}{c}\text { Group } 1 \\
\text { n (\%) }\end{array}$ & $\begin{array}{c}\text { Group } 2 \\
\text { n (\%) }\end{array}$ & $\begin{array}{l}\text { Total } \\
\text { n (\%) }\end{array}$ & $\begin{array}{c}\text { Group } 1 \\
\text { n (\%) }\end{array}$ & $\begin{array}{c}\text { Group } 2 \\
\text { n (\%) }\end{array}$ & $\begin{array}{l}\text { Total } \\
\text { n (\%) }\end{array}$ \\
\hline $0-1$ & $9(33.3)$ & $7(41.2)$ & $16(36.4)$ & - & $2(28.5)$ & $2(9.1)$ \\
\hline $2-3$ & $13(48.1)$ & $8(47.1)$ & $21(47.7)$ & $3(15.0)$ & $2(28.5)$ & $5(22.7)$ \\
\hline $4-6$ & $4(14.8)$ & $2(11.8)$ & $6(13.6)$ & $8(53.3)$ & $3(42.9)$ & $11(50.0)$ \\
\hline $7-9$ & $1(3.7)$ & - & $1(2.3)$ & $3(15.0)$ & - & $3(13.6)$ \\
\hline $10-12$ & - & - & - & $1(6.7)$ & - & $1(4.5)$ \\
\hline Total & $27(100.0)$ & $17(100.0)$ & $44(100.0)$ & $15(100.0)$ & $7(100.0)$ & $22(100.0)$ \\
\hline
\end{tabular}

SK. childhood theraphy) Rates of childhood TB are usually considered the highest among those aged 1-4 years. Thirty-nine percent of the patients in our study were less than 5 years old, whereas $62 \%$ of the patients in Kimerling's study and $66 \%$ of the patients in Albisua's study were aged less than five years old $(11,12)$. In our study, $30 \%$ of the patients were found to be in contact with adults with TB. Other studies have shown different results, for example, 58\% in Albisua's study,
$71 \%$ in Naude's study $(10,12)$. It was noted that BCG, which is a routine procedure in our country, had not been given to $19 \%$ of the patients. Positive TST, an important factor in the diagnosis of TB, was found in $72 \%$ of our patients, compared with $75 \%$ in Wong's study and $71 \%$ in Salazar's study $(13,14)$. Positive culture was detected in nine pulmonary TB patients (13\%). This ratio was higher in other studies: $39 \%$ in Starke's study and $50 \%$ in Merino's study $(15,16)$. 


\begin{tabular}{|c|c|c|}
\hline Follow-up duration & $\begin{array}{c}\text { Group } 1 \\
\text { n (\%) }\end{array}$ & $\begin{array}{c}\text { Group } 2 \\
\text { n (\%) }\end{array}$ \\
\hline 7-12 months & $9(17.6)$ & $8(12.5)$ \\
\hline 13-24 months & $12(23.5)$ & $22(34.4)$ \\
\hline $3-4$ years & $10(19.6)$ & $16(25.0)$ \\
\hline $5-7$ years & $8(15.7)$ & $10(15.6)$ \\
\hline $8-10$ years & $5(9.8)$ & $3(4.7)$ \\
\hline 11 years and more & $2(3.9)$ & - \\
\hline Lost to follow-up & $5(9.8)$ & $5(7.8)$ \\
\hline Total & $51(100.0)$ & $64(100.0)$ \\
\hline
\end{tabular}

Satyanarayana et al. reported the baseline characteristics and treatment outcomes of 1074 patients (< 15 years) from 6 selected districts of Delhi, India (17). Only $11 \%$ were under 5 years, $63 \%$ were extrapulmonary TB, and $15 \%$ were sputum smear positive where as positive sputum culture was detected in $13 \%$ of our patients. Almost all (99.5\%) patients were on intermittent short course chemotherapy (thrice weekly) with an intensive phase of 2 months (with 3 or 4 drugs) followed by a continuation phase of 4 months (with $\mathrm{H}_{3} \mathrm{R}_{3}$ ). Median duration of treatment was 182 days and $95 \%$ of patients were reported to have been successfully treated. But they did not reported the long term outcomes of these patients.

Patients with active TB should be treated with multiple agents to achieve bacterial clearance, to reduce the risk of transmission, and to prevent the emerge of drug resistance. For a successful treatment, patient centered case management and close collaboration between health care professionals and public health programs are imperative. In theory, treatment of tuberculosis is the same in developing countries and industrialized countries; but economic limitations mean that significant differences exit in practise. For both side, it is thought that ideally the curative regimens should be shorter and contain less drugs that are taken less frequently.

Although the effectiveness of intermittent therapy regimens like 6-month therapy with three drugs or 9month therapy with two drugs, has been proven by various studies, our study is significant for the reason that it demonstrates the efficacy of 6-month intermittent therapy with two drugs. No relapse occurred in the patients who received 6-month intermittent therapy, although there were four relapses in the 9-month group. Kumar et al. reported the results of 6 -month intermit- tent therapy with three drugs on 76 children with pulmonary, lymphatic and disseminated TB and found good results with no relapse (8). Naude et al. compared the results of intermittent treatment (3 drugs for 6 months) for pulmonary TB with daily treatment in a randomized controlled trial with 206 children and reported only one relapse in the intermittent group (10). Al-Dossary et al. reported the results of 175 children with pulmonary, pleural and lymph node TB who received six-month regimen with isoniazide, rifampin and pyrazinamide and detected one relapse (18). Gocmen et al. studied 110 children with TB (pulmonary and extrapulmonary) who received 9-month intermittent therapy with three drugs and 20 children who received 9month therapy with two drugs, and found one relapse (19).

Indumathi et al. reported 65 children (34 pulmonary and 31 extrapulmonary) with a mean age of 7.6 years treated with intermittent short course therapy (20). The overall cure rate was $95 \%$, and radiological response was noted in $90 \%$ of children. Only one child with meningitis had suspected relapse after 6 months.

Intermittent chemotherapy was also studied in children with various risk factors. Kiper et al. reported 15 infants aged less than 6 months, who received 9-month intermittent therapy and found good results with no relapse (9).

As contrast to these studies, a recent meta-analysis reviewed 4 randomized controlled studies comparing intermittent twice weekly therapy with daily therapy; with mainly pulmonary tuberculosis (21). Analysis of the pooled data revealed that daily therapy was superior to twice weekly intermittent therapy for children. Short course chemotherapy, with the treatment duration as short as 6 months, has become the standard practice.

In this study, we compared the effects of 6-month and 9-month intermittent chemotherapy regimen using two drugs in childhood pulmonary and extrapulmonary tuberculosis. Fifty-one patients received 9-month and 64 patients received 6 -month therapy regimens. $47 \%$ and $73 \%$ of the patients had pulmonary TB in 9-month and 6-month group, respectively, and the rest had extrapulmonary TB other than meningitis. With regard to response to treatment, no difference was detected between the two groups. There was no relapse in the 6month group, while four patients who received 9month intermittent therapy developed late relapse.

Our study has some limitations. First, it is not a randomized study; we investigated the medical records of the patients, and we did not have any chance to randomly 
select the patients into two groups. So the characteristics of the two groups were not the same, e.g. some children in group 2 had a more severe disease. This may have affected the results. Secondly, the number of the patients who had extrapulmonary TB was small. Because of this, the results of extrapulmonary TB is not as credible as pulmonary TB.

We conclude that 6-month intermittent therapy with two drugs is as efficacious as 9-month intermittent therapy in childhood pulmonary and extrapulmonary tuberculosis, other than meningitis. Further, randomized controlled studies are needed to demonstrate the efficacy of this regimen in larger populations, and in the future these studies may take this therapy regimen as the standart therapy of childhood TB.

\section{CONFLICT of INTEREST}

None declared.

\section{REFERENCES}

1. Centers for Disease Control and Prevention. Estimates of future global tuberculosis morbidity and mortality. MMWR 1993; 42: 961-4.

2. Lonnroth K, Raviglione M. Global epidemiology of tuberculosis: prospects for control. Semin Respir Crit Care Med 2008; 29: 481-91.

3. World Health Organization. Global Tuberculosis Control: Epidemiology, Strategy, Financing: WHO Report 2009. Geneva, Switzerland: World Health Organization; 2009.

4. Nelson LJ, Wells CD. Global epidemiology of childhood tuberculosis. Int J Tuberc Lung Dis 2004; 8: 636-47.

5. Marais BJ, Obihara CC, Warren RM, Schaaf HS, Gie RP, et al. The burden of childhood tuberculosis: a public health perspective. Int J Tuberc Lung Dis 2005; 9: 1305-13.

6. Chang KC, Leung CC, Grosset J, Yew WW. Treatment of tuberculosis and optimal dosing schedules. Thorax 2011; 66: 9971007.

7. Biddulph J. Short-course chemotherapy for childhood tuberculosis. Pediatr Infect Dis J 1990; 9: 794-801.

8. Kumar L, Dhand R, Singhi PD, Narasimha Rao KL, Katariya S.
A randomized trial of fully intermittent us. daily followed by intermittent short course chemotherapy for childhood tuberculosis. Pediatr Infect Dis J 1990; 9: 802-6.

9. Kiper N, Gocmen A, Dilber E, Ozcelik U. Effectiveness of short course intermittent chemotherapy for tuberculosis in young infants aged less than 6-months. Clin Pediatr 1998; 37: 433-6.

10. Te Water Naude JM, Donald PR, Hussey GD, Kibel MA, Louw A, Perkins DR, et al. Twice weekly us daily chemotherapy for childhood tuberculosis. Pediatr Infect Dis J 2000; 19: 405-10.

11. Kimerling ME. Childhood tuberculosis in Alabama: epidemiology of disease and indicators of program effectiveness, 1983 to 1993. Ped Infect Dis J 1995; 14: 678-84.

12. Albisua IS, Artiago FB, Costilla F, et al. Twenty years of pulmonary tuberculosis in children: what has changed? Ped Infect Dis J 2002; 21: 49-53.

13. Wong KS. Childhood and adolescent tuberculosis in northern Taiwan: an institutional experience during 1994-1999. ActaPediatr 2001; 90: 943-7.

14. Salazar G, Schmitz T, Cama R. Pulmonary tuberculosis in children in a developing country. Pediatrics 2001; 108: 448-53.

15. Starke JR, Taylor-Watts KT. Tuberculosis in the pediatric population of Houston, Texas. Pediatrics 1989; 84: 28-35.

16. Lundborg M, Johard U, Låstbom L, Gerde P, Camner P. Microbiology of pediatric primary pulmonary tuberculosis. Chest 2001; 119: 5 .

17. Satyanarayana S, Shivashankar R, Vashist RP, Chauhan LS, Chadha SS, et al. Characteristics and programme-defined treatment outcomes among childhood tuberculosis (TB) patients under the national TB programme in Delhi. PLoS One 2010, 12: $e 13338$

18. Al-Dossary FS, Ong LT, Correa AG, Starke JR. Treatment of childhood tuberculosis with a six month directly observed regimen of only two weeks of daily therapy. Pediatr Infect Dis $J$ 2002; 21: 91-7.

19. Gocmen A, Ozcelik U, Kiper N, et al. Short course intermittent chemotherapy in childhood tuberculosis. Infection 1993; 21: 324-7.

20. Indumathi CK, Prasanna KK, Dinakar C, Shet A, Lewin S. Intermittent short course therapy for pediatric tuberculosis. Indian Pediatr 2010; 47: 93-6.

21. Menon PR, Lodha R, Sivanandan S, Kabra SK. Intermittent or daily short course chemotherapy for tuberculosis in children: meta-analysis of randomized controlled trials. Indian Pediatr 2010; 47: 67-73. 